\title{
Farklı Deprem Senaryolarına Göre Kırşehir İli Kayıp Tahmin Analizleri
}

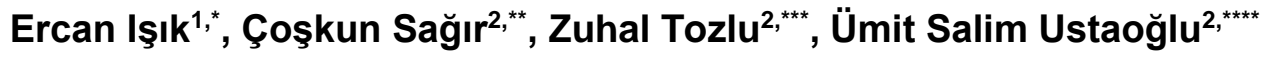 \\ ${ }^{1}$ Bitlis Eren Üniversitesi, Mühendislik-Mimarlık Fakültesi, Inşaat Mühendisliği Bölümü, 13100, Bitlis. \\ ${ }^{2}$ Çevre ve Şehircilik Bakanlığı, Altyapı ve Kentsel Dönüşüm Hizmetleri Genel Müdürlüğü, 06530, Ankara. \\ *ORCID: 0000-0001-8057-065X, **ORCID: 0000-0001-6965-4334, "**ORCID: 0000-0001-5133-8966, ***ORCID: 0000-0001-5535-236X
}

\section{Özet}

Bugünkü teknolojik imkanlar kullanılarak depremleri engellemek ve önceden haber verebilmek mümkün görünmemektedir. Ancak bazı tedbirler alınarak deprem zararlarl asgari düzeye indirgenebilir. Alınacak bu tedbirleri belirlemede kayı tahmin modelleri önemli bir yer tutmaktadır. Kayıp tahmin modelleri kullanılırken deprem senaryolarından faydalanılmaktadır. Deprem senaryolarındaki amaç herhangi bir bölge için tahmin edilen bir depremin o bölgede oluşturacă̆ hasarın saylsal olarak tahmin edilmesine dayanmaktadır. Bu çalışmada sismik olarak aktif bir bölgede yer alan Kırşehir ili için ü̧̧ farklı deprem senaryosu kullanılarak kayıp tahmin analizleri gerçekleştirilmiştir. Çalışmada ayrıca Kırş̧ehir ilinin depremselliği hakkında bilgiler verilmiştir. Her üç deprem senaryosu içinde ayrı ayrı bina hasarları can ve mal kayıpları ile yapısal hasar kaynaklı mali kayıplar elde edilmiştir. Bina hasarları yazılım programında yer alan iki farklı yöntem kullanılarak hesaplanmıştır. En büyük yapısal hasarlar Akpınar Depreminin dikkate alındığl Senaryo 2 depreminde gözlemlenmiştir. Çalışma modern afet yönetimi ve kentsel dönüşüm açısından önemli bir yere sahiptir. Bu tür çalışmalar afet öncesi hazırlık noktasında karar vericilerin destek aracı olarak kullanılabilecektir.

Anahtar Sözcükler

Deprem, Senaryo, Kayıp Tahmini, Yapısal Hasar, Afet Yönetimi, Kırşehir

\section{Loss Estimation for Kırşehir Province According to Different Earthquake Scenarios}

\begin{abstract}
It is not possible to prevent earthquakes and to give notice in advance by using contemporary technological opportunities. However, it is possible to take precautions in order to minimize losses in case of an earthquake. Loss estimation models take a significant role in determining these precautions. Earthquake scenarios are used when preparing loss estimation models. The objective in earthquake scenarios is to estimate the economic losses, the damage to infrastructure, and the social impact associated with the potential earthquake. In this paper, it was discussed loss estimation models of three different earthquake scenarios developed for Kirşehir where is a seismically active province of Turkey. In the study, information about the seismicity of Kirşehir province was also given. Individual building damages, life and property losses and financial losses due to structural damage were obtained within each of the three earthquake scenarios. Building damages were calculated by two different methods which included in the software package. The greatest structural damage was observed in the Scenario 2 earthquake that is Akpinar Earthquake. The work has an important place in terms of modern disaster management and urban transformation. Such studies can be used as a support tool for decision makers at the pre-disaster preparation stage.
\end{abstract}

$\underline{\text { Keywords }}$

Earthquake, Scenario, Loss Estimation, Structural Damage, Disaster Management, Kırşehir

\section{Giriş}

Depremlerin sıkça yaşandığı ülkemizde, deprem konusu hakkında çalışmalar her geçen gün önemini artırmaktadır. Depremin, günümüz teknolojileri ile önceden belirlenme imkanı bulunmamaktadır. Bundan dolayı oluşabilecek can ve mal kayıplarının engellenmesi mümkün görünmemektedir. Ancak deprem öncesi alınacak önlemler ile deprem zararları azaltılabilmektedir. Bu da günümüz modern afet yönetim anlayışının önemli parçalarından birini oluşturmaktadır. Deprem tehlikesinin etkileyeceği bölgelerde yapılan bir takım hesaplamalar ile deprem zararlarının azaltılması mümkündür.

Deprem tehlikesi, belirli bir bölgede ve belli bir zaman diliminde olası depremden dolayı hasar ve can kaybı oluşturabilecek yer hareketinin meydana gelme ihtimalidir. Deprem riski, deprem nedeni ile oluşabilecek mal ve can kaybı ile hasar ihtimali olarak tanımlanabilir (Yunatçı ve Çetin, 2007; Türkelli 2008; Eyidoğan 2003). Sismik tehlike çalışmaları ile herhangi bir yerleşim biriminde oluşabilecek depremlerin büyüklüğü belirlenebilmektedir. Deprem senaryoları ile bu bölgelerin hangi düzeyde etkilenebileceği belirlenmeye çalışılmaktadır (Özmen 2008). 
Deprem senaryolarındaki amaç herhangi bir bölge için tahmin edilen bir depremin o bölgede oluşturacağı hasarın sayısal olarak tahmin edilmesine dayanmaktadır. Olası bir depremde meydana gelebilecek can ve mal kayıplarının tahmini olarak belirlenerek gerekli önlemlerin alınması ile oluşabilecek zarar miktarının azaltılması sağlanabilmektedir (Işık vd. 2017). Bir bölge için bu hesaplamalar yapılırken herhangi bir senaryo depreminin oluşması durumunda çalışılan bölgedeki yapı stokunda meydana gelebilecek olan hasar miktarının belirlenmesi amaçlanmaktadır. Buradan hareketle sosyal ve ekonomik kayıplar da hesaplanabilmektedir (Işı1k vd. 2018).

Depremin etkilemesi öngörülen alanları, binaları ve deprem sonucunda oluşacak ekonomik kaybın hesaplanması olası bir depreme hazırlanmak için gerekli işlemlerden biridir. Deprem hasar tahmini için gerekli olan en önemli faktör, bütün bölgeyi içine alan senaryoları uygulayabilecek ve bu senaryolara dayalı risk analizleri yapabilecek bir yazılımdır (Erdik ve Durukal 2008). Bu analizlerin yapılması için geliştirilen farklı yazılım programları bulunmaktadır. Bu çalışmada Earthquake Loss Estimation Routine (ELER) yazılımı kullanılarak Kırşehir ili için olası deprem senaryolarında oluşabilecek hasar tespit analizleri yapılmıştır.

Çalışmada öncellikli olarak Kırşehir ilinin tamamında alan analizleri yapılmıştır. Sonraki aşamada Kırşehir ili için deprem tehlikesi tanımlanmıştır. Bu işlemden sonra, Kırşehir ilini etkileyebilecek üç farklı deprem senaryosu dikkate alınmıştır. Senaryo 1 depremi olarak Gümüşkent Fayı'nda oluşabilecek M=6.8; Senaryo 2 depremi olarak Akpınar Fayı'nda 1938 yılında oluşan M=6.8; Senaryo 3 depremi olarak Akpınar Fayı'nda oluşabilecek M=6.3 büyüklüğünde deprem dikkate alınmıştır. Senaryo 3 depremi, Senaryo 2 depremi ile karşılaştırma yapılabilmesi adına kullanılmıştır. Dikkate alınan bu senaryolar 1şığında tahmini hasarlar elde edilmiştir. Elde edilen bu veriler yardımı ile Kırşehir ilinde oluşabilecek deprem senaryoları sonucu olası kayıplar belirlenmiştir. Kırşehir ili farklı deprem senaryoları kullanılarak oluşabilecek can ve mal kayıplarının hesaplanması amaçlanmıştır. Bu hesaplamalar yapılırken ELER yazılım programı kullanılmıştır.

\section{Yöntem}

Çalışmada Kırşehir ili ve ilçelerinin tamamı dikkate alınmıştır. Kırşehir ili, İç Anadolu Bölgesi'nin orta kesiminde yer almaktadır. $39^{\circ} 41^{\prime}-39^{\circ} 48^{\prime}$ kuzey enlemleri ile $33^{\circ} 25^{\prime}-34^{\circ} 43^{\prime}$ doğu boylamları arasında bulunan Kırşehir, Orta Kızılırmak Havzası'nda yer almaktadır. Kırşehir, batıda Ankara, güneyde Aksaray, doğu ve güneydoğuda Nevşehir, kuzeydoğu ve doğuda Yozgat, kuzeybatıda Kırıkkale illeri ile çevrelenmiştir. Kırşehir ilinde merkez ilçe dahil olmak üzere yedi ilçe dikkate alınmıştır. Kırşehir iline ait ilçeler ve konumları Şekil 1’de gösterilmiştir.

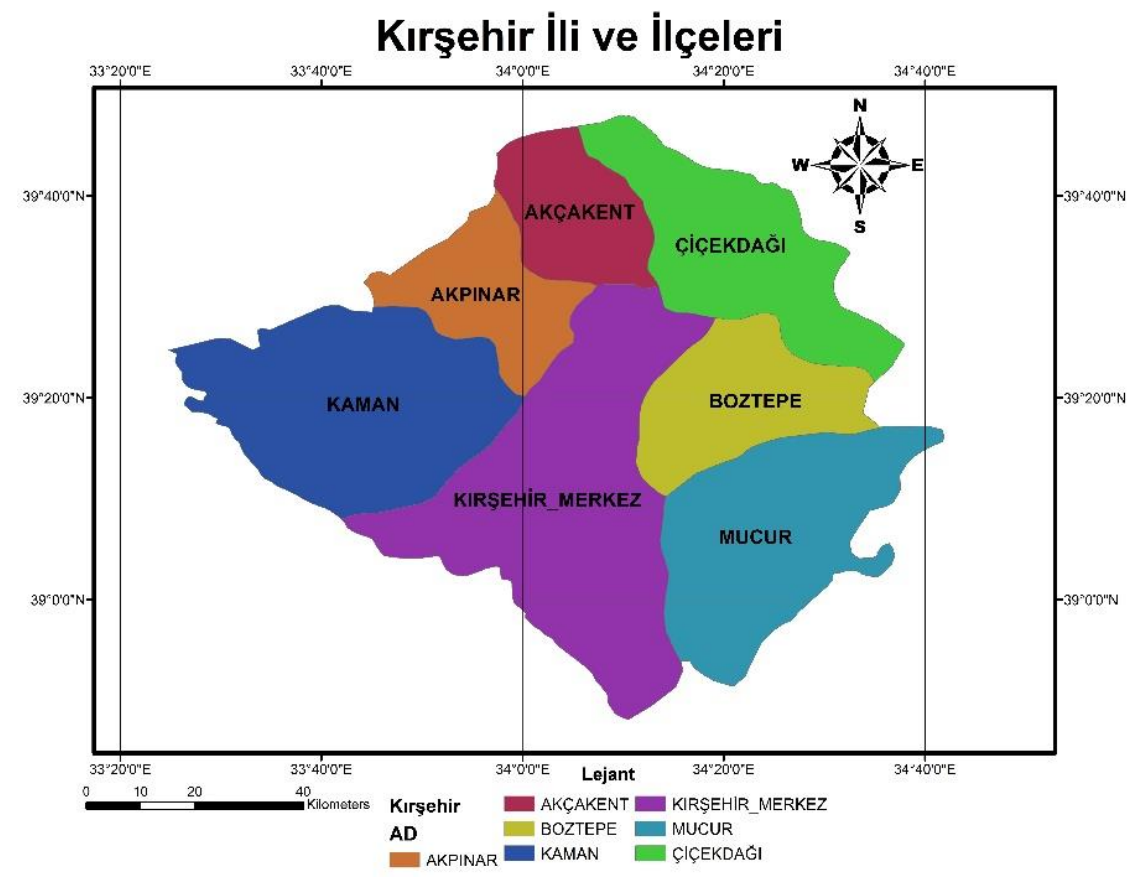

Şekil 1: Kırşehir ili ilçeleri ve konumu

Günümüzde bilgi teknolojilerin gelişimine uyumlu bir şekilde depremlerden dolayı oluşabilecek kayıplar hesaplanabilmektedir. Son yıllarda depremlerin oluşturduğu hasarlar çerçevesinde modern afet yönetimi kapsamında kullanılabilecek kayıp tahmin analizleri için birçok yazılım programı geliştirilmiştir. Displacement - Based Earthquake Loss Assessment (DBELA), gelecekte oluşacak depremlerden dolayı kayıpları tahmin etmektedir. Bu yazılımda bölgenin depremselliği, yerel zemin koşulları ile yapı stok özelliklerinin bilinmesi ile kayıp tahmin analizleri yapılabilmektedir. Yapılan hesaplamalar deplasmana dayalı olarak yapılmaktadır (Crowley ve Bommer 2006; Bal vd. 2008). 
Orta Amerika Deprem Merkezi tarafından geliştirilen MAEVIZ adlı kayıp tahmin yazılımında deprem senaryosu oluşturulmakta ve coğrafi bilgi sistemine göre kayıp tahminleri yapılmaktadır (URL-1 2007). Potansiyel depremlerin konumu ile büyüklüğü, bina stoku, yerel jeoloji gibi parametreleri matematiksel formüller yardımı ile kayıp tahmin analizlerinde kullanan bir diğer yazılım HAZUS programıdır (Bommer vd. 2002; Zülfikar vd. 2017; HAZUS, 2003; Erdik vd. 2003). Seismic Loss Estimation (SELENA), HAZUS altyapısını kullanmaktadır. SELENA herhangi bir Coğrafi Bilgi Sisteminden bağımsız olarak çalışabilmektedir (Molina vd. 2010; Makhoul ve Argyroudis 2018). Earthquake Loss Estimation Routine (ELER), Avrupa Birliği tarafından yapılan proje kapsamında, depremin toplum üzerindeki sosyal, fiziksel ve ekonomik sonuçlarının gösterilmesini içeren araştırma projesinin bir parçasıdır. Bu proje Boğaziçi Üniversitesi Deprem Mühendisliği Anabilim Dalında geliştirilmiştir (Erdik vd. 2010; Hancılar vd. 2010; ELER 2010). Bu yazılım programlarının genel çalışma esasları Şekil 2'de gösterilmiştir.

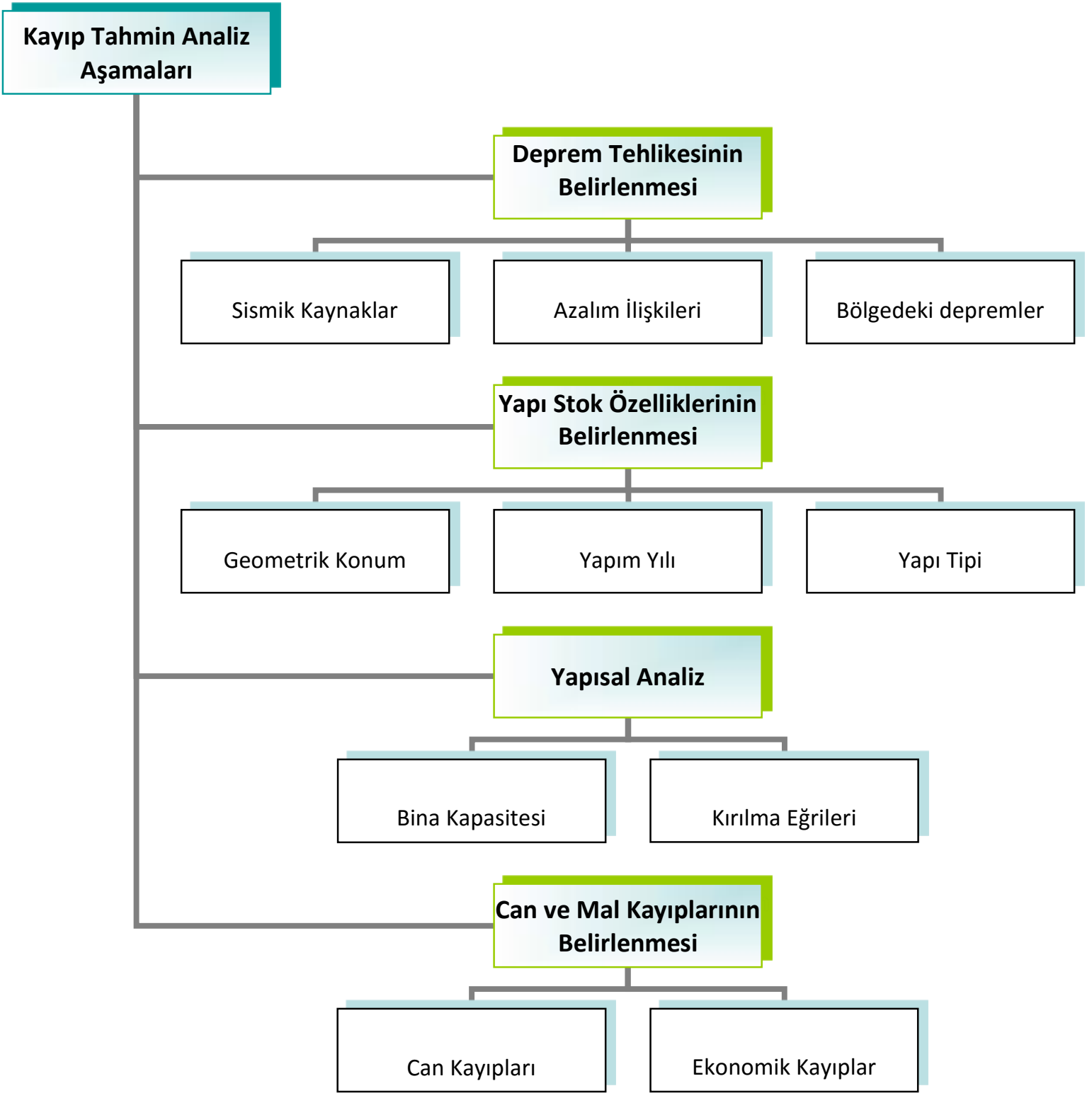

Şekil 2: Kayıp tahmin analiz aşamaları

Orta Anadolu Bölgesinde yer alan Kırşehir ili ve civarı depremsellik açısından incelenmeye değer bir konumda bulunmaktadır. Kırşehir ilinin deprem haritası Şekil 3'te gösterilmiştir. Özellikle 1938 yılında meydana gelen Akpınar depremi, Kırşehir ilinde büyük yıkımlara neden olmuştur. Akpınar Depreminin aletsel dış merkezi, 39.50 K-33.70 D arasında ve büyüklüğü $\mathrm{M}=6.8$ olarak belirlenmiştir. Bazı bölgelerde zeminde kum kraterleri oluşmuş ve bunun sonucu olarak zemin sıvılaşmaları gözlemlenmiştir. İlin değişik yerlerinde büyük yapısal hasarlar meydana gelmiştir. Yapısal hasarlar genel olarak zayıf zeminler üzerine inşa edilmiş yapılarda oluşmuştur. Depremin en büyük etkileri Kırşehir ilinde gözlemlenmiştir. 
En çok etkilenen bölge Akpınar ve bu ilçeye bağlı köyler olmuştur. Ayrıca bu deprem Kırşehir'e komşu olan illerde de hasarlara neden olmuştur (Şahin 2016; Temiz ve Gökten 2011). Bu açıdan 1938 Akpınar depremi Kırşehir ili için yapılacak kayıp tahmin analizlerinde önemli bir yere sahiptir.

Kırşehir ilinin içinde bulunduğu Orta Anadolu ve yakın çevresinin yapısal unsurları Şekil 3 'te verilmiştir. Genel olarak Kırşehir ilinde etkili olabilecek faylar; Akpınar Fayı (AF), Salanda Fayı (SF), Tuzgölü Fay Zonu (TFZ), Yıldızeli Fay Zonu (YFZ), Orta Anadolu Fay Zonu (CAFZ) olarak ifade edilebilir (Bozkurt 2001; Gömcü 2013; Maden vd. 2009; Temiz 2004; Yıldız 2008). Çalışma Kırşehir ilinin tamamını kapsamaktadır. Çalışmaya konu olan bölge sınırları Şekil 5'te gösterilmiştir.

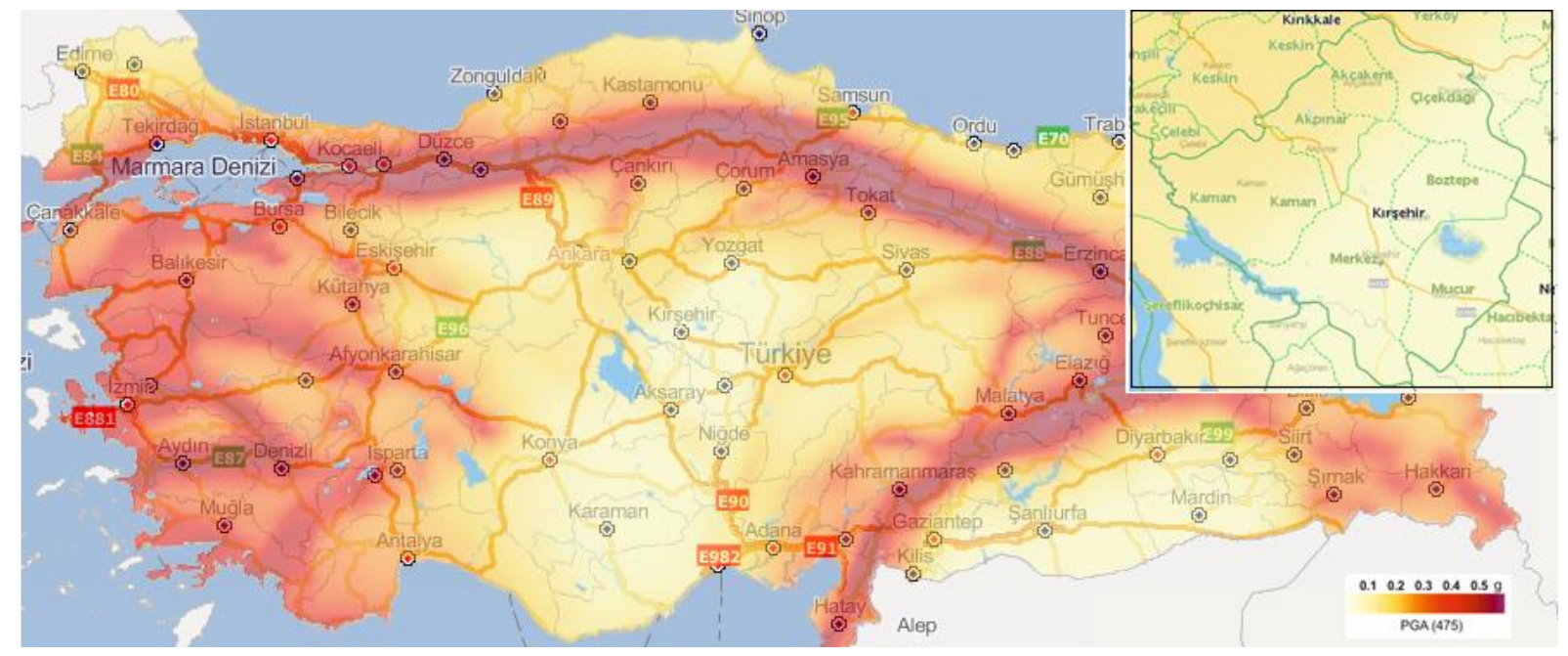

Şekil 3: Kırşehir ili deprem haritası (URL-2 2018'den düzenlenerek alınmıştır)

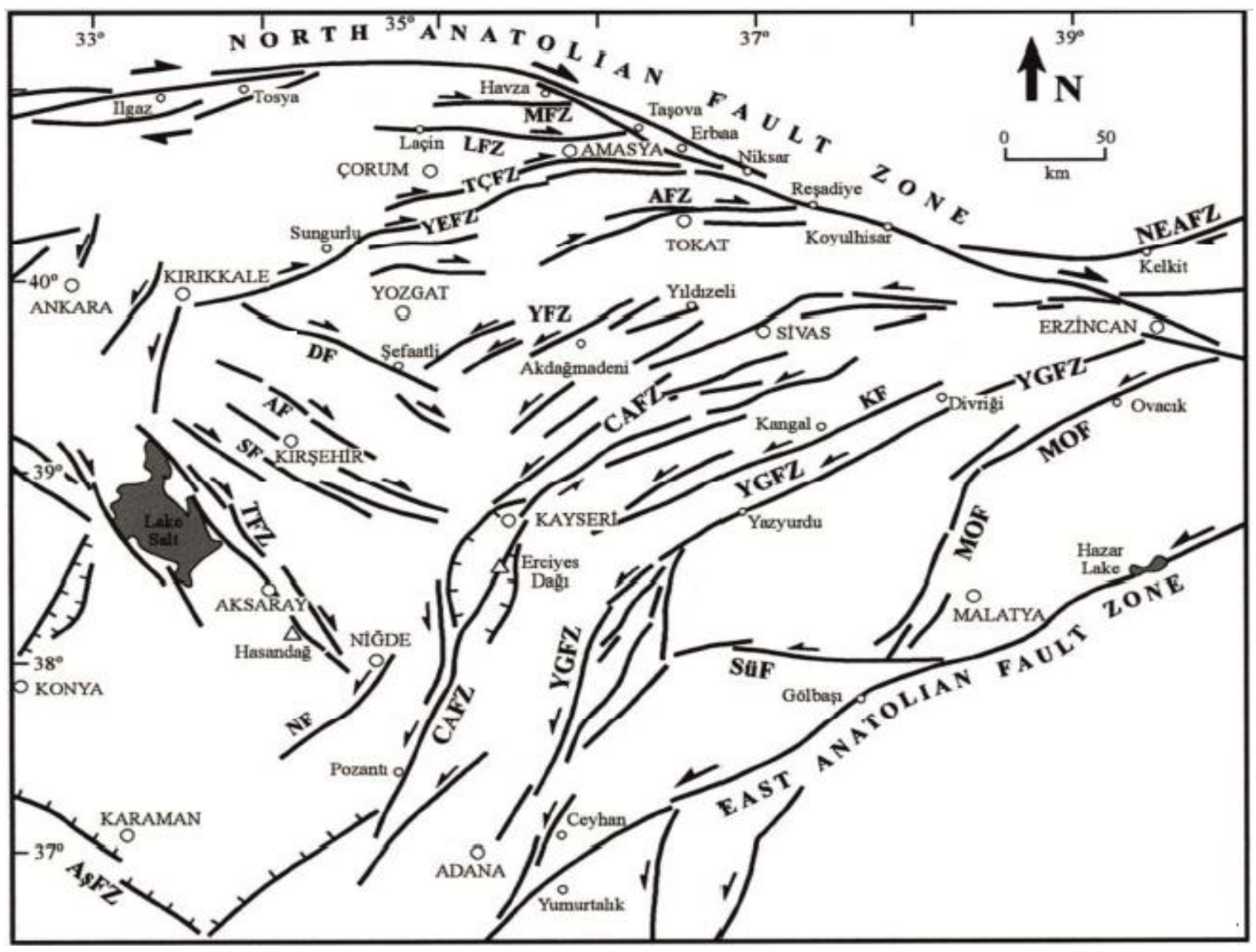

Şekil 4: Orta Anadolu Bölgesi'nde bulunan ana yapısal unsurları gösteren basitleştirilmiş harita (Bozkurt 2001) 


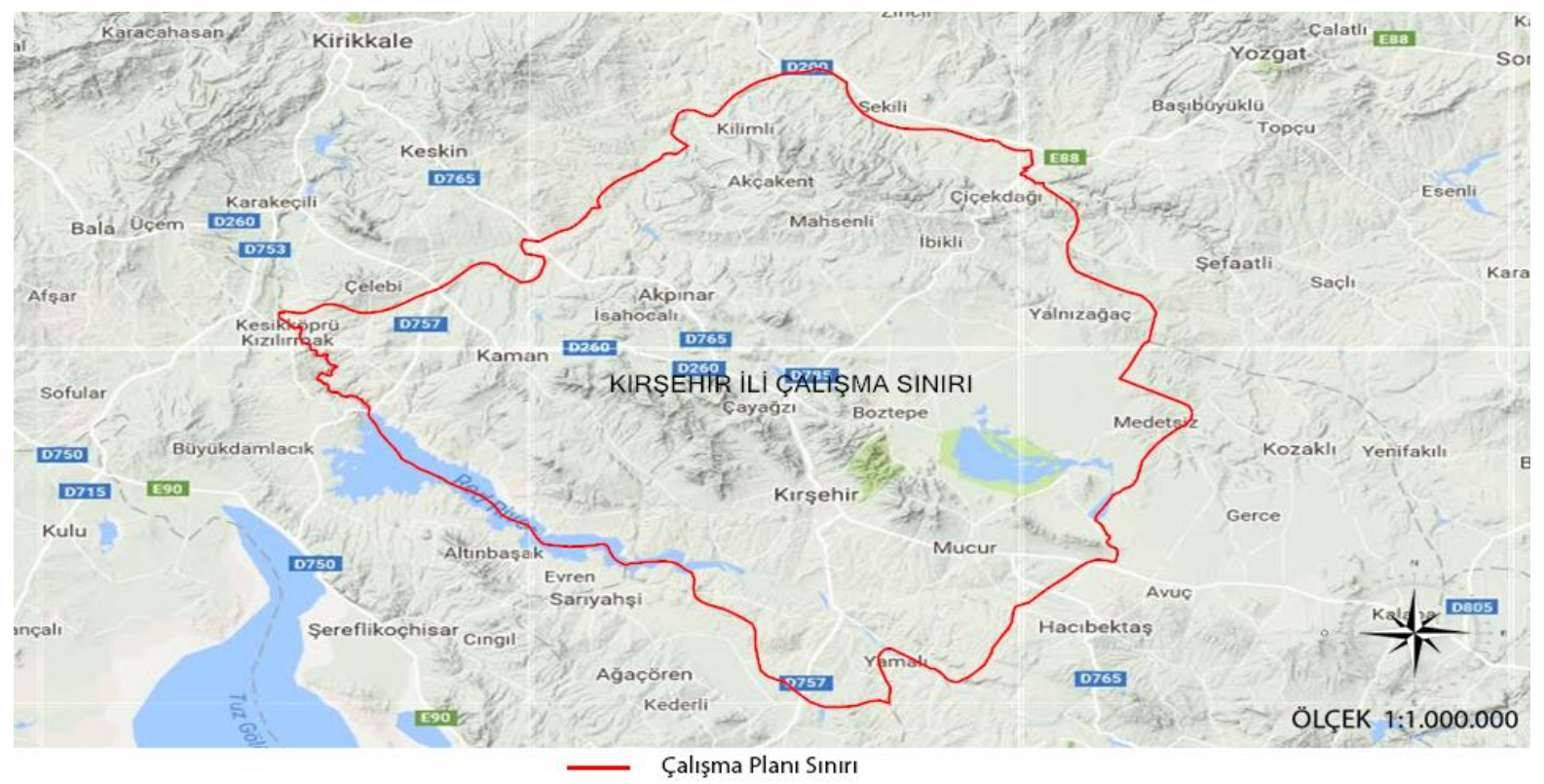

Şekil 5: Çalışmaya konu olan bölge sınırları

Kırşehir ili için üretilen $0.002^{\circ}$ aralıklı grid verisine ait örnek bir kesit Şekil 6'da gösterilmiştir. Bu aralık ile daha hassas sonuçlar alınabilmektedir.

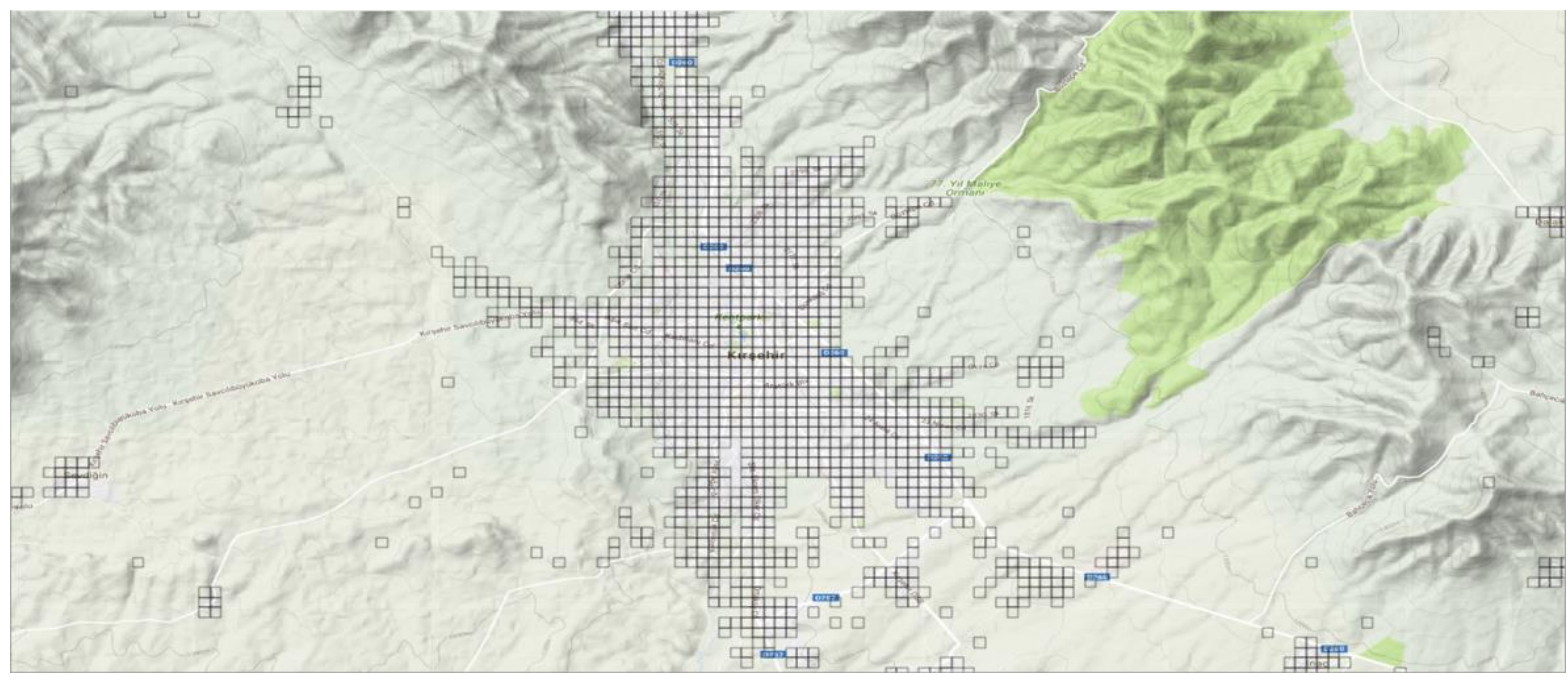

Şekil 6: Kırşehir ili için üretilen $0.002^{\circ}$ aralıklı grid verisine ait örnek bir kesit

Çalışmada Kırşehir ilinin tamamında bulunan binalar yazılım programına uygun şekilde oluşturulan formlar kullanılarak arazi çalışmaları sonucu veri tabanına işlenmiştir. Çalışma kapsamında sahada yapılan incelemeler sonucu elde edilen bina lokasyon dağılımı Şekil 7'de gösterilmiştir. 


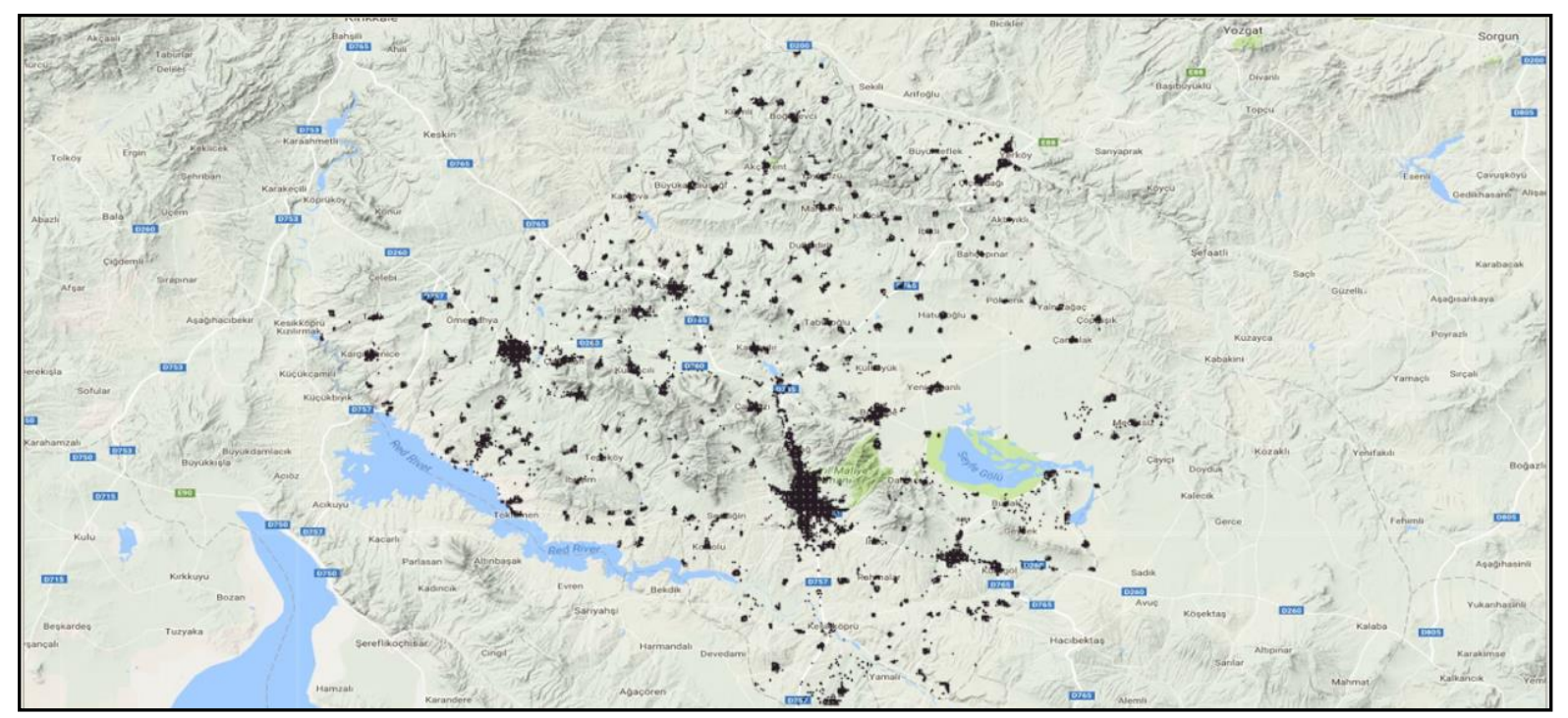

Şekil 7: Kırşehir ili bina lokasyon dağılım haritası

Yerel zemin koşulları deprem ve yapı ilişkisi açısından önemli bir yere sahiptir (Işı1k vd. 2016). Çalışmada yerel zemin koşulları $\mathrm{V}_{\mathrm{S} 30}$ ve SPTN-30 olmak üzere iki farklı veri şeklinde ifade edilmiştir. Kırşehir için bu değerler çalışmaya esas olan projenin "Yer Bilimsel Etüt Bilgi Sistemi" kısmında veri tabanına aktarılan güncel verilerden doğrudan alınmıştır. Çalışmada dikkate alınan üç farklı deprem senaryosu için elde edilen en büyük yer ivmesi (PGA) haritaları Şekil 8'de gösterilmiştir.
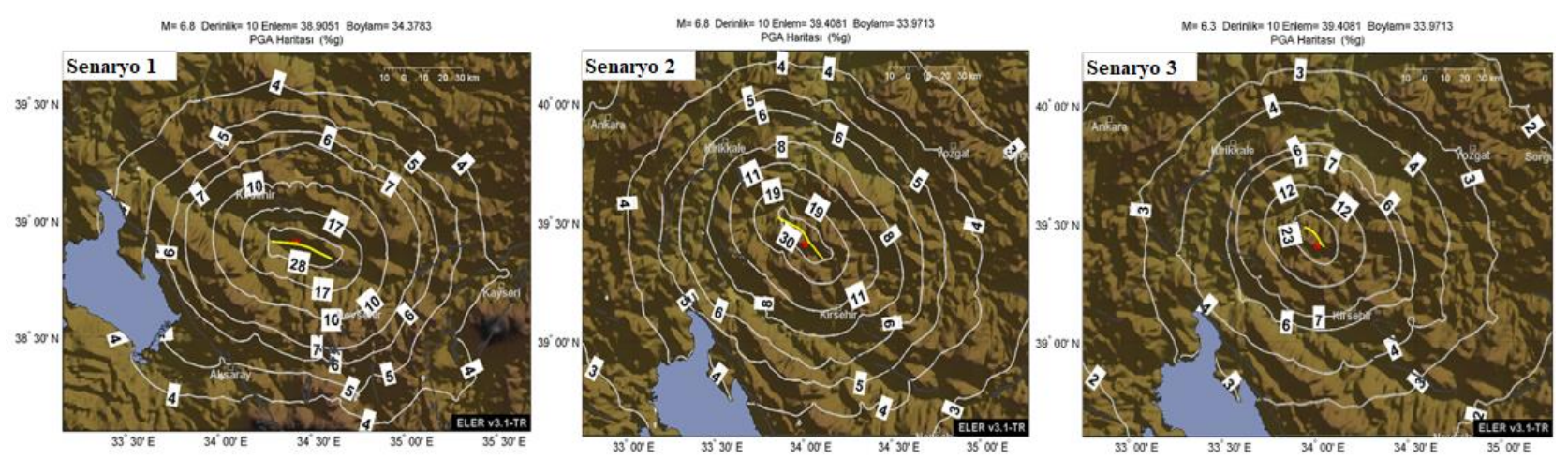

Şekil 8: Senaryo depremleri için elde edilen en büyük yer ivmesi değerleri

Kırşehir ili için çalışmada dikkate alınan farklı deprem senaryoları için en büyük yer hızı (PGV) haritaları Şekil 9'da gösterilmiştir.
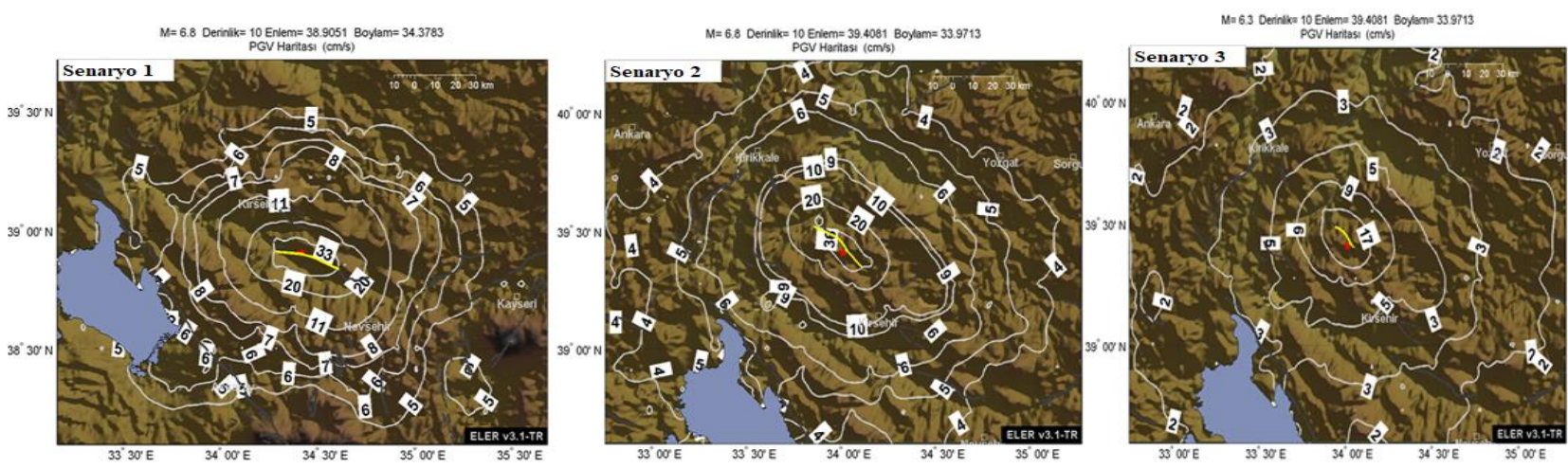

Şekil 9: Senaryo depremleri için elde edilen en büyük yer hızı değerleri

Sahadan toplanacak bina özellikleri proje kapsamında ihtiyaç duyulacak parametrelere göre belirlenmiştir. Sahada yapılan çalışmalar sonucu binalar ile ilgili bu veriler tabletler vasıtası ile veri tabanına aktarılmıştır. Veri tabanına eklenen 
bilgiler ışığında grid bazlı bina envanteri toplamda 90337 adet bina içermektedir. Kırşehir ili bina envanteri deprem hasar tahmini yazılım programına uygun şekilde sınıflandırılmıştır. Her bir sınıfta bulunan toplam bina sayısı Tablo 1'de verilmiştir.

Tablo 1: Kırşehir İli bina envanteri sınıflandırması

\begin{tabular}{|l|c|c|c|}
\hline Taşıyıcı Sistem Tipi & $\begin{array}{c}\text { Kat } \\
\text { Adedi }\end{array}$ & Inş̧a Yılı & Bina Sayısı \\
\hline Yı̆̆ma & $1-4$ & 1979 ve öncesi & 17676 \\
\hline Yı̆̆ma & $1-4$ & $1980-2000$ & 24548 \\
\hline Yığma & $1-4$ & 2001 ve sonrası & 4 \\
\hline Prekast & $1-4$ & 1979 ve öncesi & 27 \\
\hline Prekast & $1-4$ & $1980-2000$ & 59 \\
\hline Betonarme çerçeve & $1-4$ & 1979 ve öncesi & 2487 \\
\hline Betonarme çerçeve & $1-4$ & $1980-2000$ & 9540 \\
\hline Betonarme çerçeve & $1-4$ & 2001 ve sonrasi & 32843 \\
\hline Betonarme çerçeve & $5-8$ & 1979 ve öncesi & 205 \\
\hline Betonarme çerçeve & $5-8$ & $1980-2000$ & 1354 \\
\hline Betonarme çerçeve & $5-8$ & 2001 ve sonrasi & 1471 \\
\hline Betonarme çerçeve & $9-19$ & $1980-2000$ & 11 \\
\hline Betonarme çerçeve & $9-19$ & 2001 ve sonrasi & 29 \\
\hline Betonarme perde duvar & $1-4$ & 1979 ve öncesi & 8 \\
\hline Betonarme perde duvar & $1-4$ & $1980-2000$ & 25 \\
\hline Betonarme perde duvar & $1-4$ & 2001 ve sonrasi & 50 \\
\hline Toplam Bina Sayısı & \multicolumn{3}{|r|}{} \\
\hline
\end{tabular}

NVI entegrasyonu sağlanamadığı için nüfus verileri TÜİK ve sahadan toplanan bina verileri ile hesaplanmıştır. Kırşehir Valiliği (URL-3 2016) tarafından yayınlanan TÜIKK verilerine göre Kırşehir nüfusu 225.197 kişi ve ortalama hane halkı büyüklüğü 3.2 olarak görülmektedir. Bu değer, Kırşehir ili için mahalle ve köy nüfus dağılımları göz önüne alınarak yerleşim veya iş yeri olarak görülen yapılara işlenmiş, buna göre her bir yapı için nüfus dağılımı hesaplanmıştır. Çalışmada kullanılan grid bazlı nüfus dağılımı Şekil 10'da gösterilmiştir.

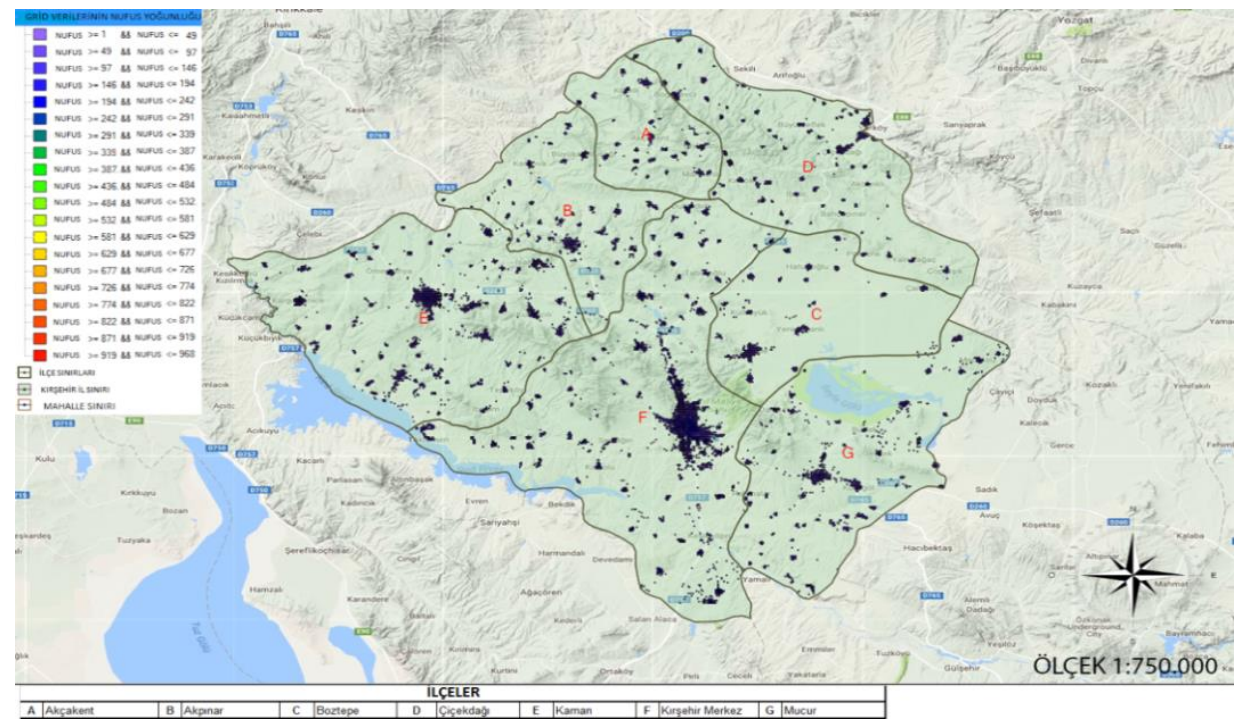

Şekil 10: Kırşehir il nüfusu tematik haritası

Çalışmada kullanılmak üzere üç farklı senaryo depremi dikkate alınmıştır. Senaryo 1 depremi olarak Akpınar depremi ile aynı büyüklükte $(\mathrm{M}=6.8)$ olmak üzere Gümüşkent Fayı üzerinde bir nokta seçilmiştir. Senaryo 2 depremi olarak Akpınar fayında oluşan 19.04.1938 Akpınar depremi $(M=6.8)$ dikkate alınmıştır. Bu deprem Kırşehir ve yakın civarında oluşan en önemli deprem verisi olarak karşımıza çıkmaktadır. Senaryo 3 depremi olarak da yine Akpınar fayında oluşması düşünülen $\mathrm{M}=6.3$ 'lük deprem dikkate alınmıştır. Her üç deprem senaryosu için elde edilen sonuçlar aşağıda verilmiştir. Depremin hemen sonrasında hasar düzeyleri can kaybı ve yaralanmalar ile ifade edilmektedir. 
Depremin en belirgin etkisi yapılaşma süreci tamamlanmış çevrenin yıkımıdır. Deprem yapıların tamamının hasar görmesine sebebiyet verebilmektedir. Zaman zaman yapıların tüm fonksiyonlarını kaybetmesine neden olabilmektedir. $\mathrm{Bu}$ bölümde, çalışmada kullanılan senaryo depremleri için Kapasite Spektrumu Yöntemi (CSM) ve Katsayı Yöntemi (CM) modelleri ayrı ayrı kullanılarak, bina hasarı ve can kaybı tahminleri tablolar halinde sunulmaktadır. Her iki yöntemde de deprem etkisi altındaki yapılar, çok ağır hasar, ağır hasar, orta hasar, hafif hasar ve hasarsız olmak üzere beş farklı yapı sınıfına ayrılarak sınıflandırmalar yapılmıştır. Her iki yöntem için yapılan hesaplamalardan sonra bu iki yöntem için ortalama değerler hesaplanmıştır. Senaryo 1 için Gümüşkent Fayı üzerinde (X:38.9051, Y:34.3783) koordinatlarında $(\mathrm{M}=6.8)$ büyüklüğünde bir deprem ile hazırlanan senaryodur. Senaryo 1 depremi için elde edilen bina hasar tahmin sonuçları Tablo 2'de gösterilmiştir.

Tablo 2: Senaryo 1 için bina hasarı tahmin sonuçları

\begin{tabular}{|c|c|c|c|c|}
\hline \multirow{2}{*}{ Hasar Seviyesi } & \multicolumn{2}{|c|}{ Yöntem } & \multirow{2}{*}{ Ortalama } & $\begin{array}{c}\text { Toplam Bina } \\
\text { Sayısına oranı }\end{array}$ \\
\cline { 2 - 3 } & CSM & \multicolumn{2}{|c|}{ CM } & \\
\cline { 2 - 3 } & \multicolumn{2}{|c|}{ Bina Sayısı } & 390 & \%1'den az \\
\hline Çok Ă̆ır Hasar & 569 & 211 & 1006 & $\% 1.1$ \\
\hline Ağır Hasar & 1127 & 885 & 3815 & $\% 4.2$ \\
\hline Orta Hasar & 3645 & 3986 & 8928 & $\% 9.9$ \\
\hline Hafif Hasar & 8231 & 9624 & 76198 & $\% 84$ \\
\hline Hasarsız & 76765 & 75631 & & \\
\hline
\end{tabular}

Senaryo 2 depremi olarak Akpınar fayında (39.4080, 33.9712) koordinatlarında ve 19.04.1938 tarihinde oluşan Akpınar depremi $(\mathrm{M}=6.8)$ ile hazırlanan senaryodur. Senaryo 2 depremi için elde edilen bina hasar tahmin sonuçları Tablo 3 'te gösterilmiştir.

Tablo 3: Bina hasarı tahmin sonuçları: Senaryo $2(M=6,8)$

\begin{tabular}{|c|c|c|c|c|}
\hline \multirow{2}{*}{ Hasar Seviyesi } & \multicolumn{2}{|c|}{ Yöntem } & \multirow{2}{*}{ Ortalama } & $\begin{array}{c}\text { Toplam Bina } \\
\text { Sayısına oranı }\end{array}$ \\
\cline { 2 - 3 } & CSM & CM & \\
\cline { 2 - 3 } Çok Ăğır Hasar & 2033 & 786 & 1410 & $\% 2$ \\
\hline Ağır Hasar & 2965 & 2400 & 2683 & $\% 3$ \\
\hline Orta Hasar & 7742 & 8404 & 8073 & $\% 9$ \\
\hline Hafif Hasar & 14698 & 16796 & 15747 & $\% 17$ \\
\hline Hasarsız & 62899 & 61951 & 62425 & $\% 69$ \\
\hline
\end{tabular}

Senaryo 3 için ise (39.4080, 33.9712) koordinatlarındaki 1939 Akpınar Depremi’nin oluştuğu fayda fakat büyüklüğü $(\mathrm{M}=6.3)$ olan bir deprem senaryosu seçilmiştir. Senaryo 3 depremi için elde edilen bina hasar tahmin sonuçları Tablo 4'te gösterilmiştir. 
Tablo 4: Bina hasarı tahmin sonuçları: Senaryo 3 (M=6.3)

\begin{tabular}{|c|c|c|c|c|}
\hline \multirow{2}{*}{ Hasar Seviyesi } & \multicolumn{2}{|c|}{ Yöntem } & \multirow{2}{*}{ Ortalama } & $\begin{array}{c}\text { Toplam Bina } \\
\text { Sayısına oranı }\end{array}$ \\
\cline { 2 - 3 } & CSM & CM & \\
\cline { 2 - 3 } & \multicolumn{2}{|c|}{ Bina Sayısı } & 516 & $\% 1$ 'den az \\
\hline Çok Ă̆ır Hasar & 620 & 412 & 1262 & $\% 1,4$ \\
\hline Ăğır Hasar & 1228 & 1295 & 4107 & $\% 4,5$ \\
\hline Orta Hasar & 3659 & 4555 & 9399 & $\% 10,4$ \\
\hline Hafif Hasar & 8260 & 10539 & 75053 & $\% 83,1$ \\
\hline Hasarsız & 76570 & 73536 & \\
\hline
\end{tabular}

Depremler öncelikli olarak insan hayatı olmak üzere her türlü sosyal yapılanma ve ekonomik hayat üzerinde çok ciddi yıkımlara neden olmaktadır. Depremin hemen sonrasında hasar düzeyleri can kaybı ve yaralanmalar ile ifade edilmektedir. Bu proje kapsamında ELER yazılım programı içinde yer alan iki farklı model yardımı ile hesaplamalar yapılmıştır. Can kaybı ve yaralanma tahminleri hasarlı bina dağılımlarına bağlı olarak HAZUS-MH (2003) ve KOERI (2002) modelleriyle hesaplanmıştır.

KOERİ (2002) modelinde Türkiye'de yaşanan depremler dikkate alınarak yığma ve betonarme yapılar için yaralanma oranları matrisi tarif edilmiştir. Bu matrisler yardımı ile elde edilen oranlar deprem anında binada bulunan insan sayısı ile çarpılmaktadır. Çok ağır hasar tanımı altında verilen oranlardaki fark binanın yıkılma şekli ile ilgilidir. Bu hanedeki birinci oran tamamen yıkılmayan (göçmeyen) binalarla ilişkindir. İkinci oran ise tamamen yıkılan (göçen) binalardaki yaralanma oranlarını vermektedir. Bir depremdeki toplam ölü sayısını tamamen yıkılan (göçen) binalar belirlemektedir.

HAZUS-MH (2003) modeli ölüm ve yaralanmaları bina hasarı ile doğrudan ilişkilendirmektedir. Yapısal hasarın az olduğu yerlerde yaralanmalar daha çok yapısal olmayan hasardan kaynaklanmakta, yapısal hasarın ağır olduğu yerlerde ise çok sayıda ölüm meydana gelmesi ihtimali bulunmaktadır. Ancak depremlerdeki ölüm ve yaralanmalarla ilgili istatistiki bilgilerde ölümlerin ne tip binalarda ve ne tip hasarlardan kaynaklandığına dair hususlar yer almadığı için, kullanılan yaralanma oranlarının yaklaşık olduğu hususuna dikkat edilmelidir. Çalışmada kullanılan iki farklı senaryo depremi için iki farklı can kaybı tahmin modeli kullanılarak can kayıp tahminleri aşağıda hesaplanmıştır.

Çalışmada kullanılan Senaryo 1 bir depremi için oluşabilecek can kaybı ve yaralanma tahmin sonuçları Tablo 5'te verilmiştir.

Tablo 5: Can kaybı ve yaralanma tahmin sonuçları: Senaryo $1(M=6,8)$

\begin{tabular}{|c|c|c|c|c|c|}
\hline \multirow{4}{*}{ Yaralanma Seviyesi } & \multicolumn{4}{|c|}{ Yöntem } & \multirow{3}{*}{ Ortalama } \\
\hline & \multicolumn{2}{|c|}{ CSM } & \multicolumn{2}{|c|}{ CM } & \\
\hline & KOERI & HAZUS & KOERI & HAZUS & \\
\hline & \multicolumn{5}{|c|}{ Kişi Sayısı } \\
\hline $\begin{array}{c}\text { Seviye } 4 \\
\text { (Can Kaybı) }\end{array}$ & 61 & 13 & 24 & 5 & 26 \\
\hline $\begin{array}{c}\text { Seviye } 3 \\
\text { (Ă̆ır Yaralı) } \\
\end{array}$ & 61 & 7 & 24 & 3 & 24 \\
\hline $\begin{array}{c}\text { Seviye } 2 \\
\text { (Hastanede Tedavi) }\end{array}$ & 133 & 45 & 61 & 21 & 65 \\
\hline $\begin{array}{c}\text { Seviye 1 } \\
\text { (Hafif Yaralı) } \\
\end{array}$ & 249 & 182 & 137 & 115 & 171 \\
\hline
\end{tabular}

Çalışmada kullanılan Senaryo 2 bir depremi için oluşabilecek can kaybı ve yaralanma tahmin sonuçları Tablo 6'da verilmiştir. 
Tablo 6: Can kaybı ve yaralanma tahmin sonuçları: Senaryo $2(M=6,8)$

\begin{tabular}{|c|c|c|c|c|c|}
\hline \multirow{2}{*}{ Yaralanma Seviyesi } & \multicolumn{4}{|c|}{ Yöntem } & \multirow{2}{*}{ Ortalama } \\
\cline { 2 - 5 } & \multicolumn{2}{|c|}{ CSM } & \multicolumn{2}{c|}{ CM } & \\
\cline { 2 - 5 } & KOERI & HAZUS & KOERI & HAZUS & \\
\cline { 2 - 6 } & \multicolumn{5}{|c|}{ Kişi Sayısı } \\
\hline $\begin{array}{c}\text { Seviye 4 } \\
\text { (Can Kaybı) }\end{array}$ & 130 & 28 & 57 & 12 & 57 \\
\hline $\begin{array}{c}\text { Seviye 3 } \\
\text { (ĂğI Yaralı) }\end{array}$ & 130 & 14 & 57 & 6 & 52 \\
\hline $\begin{array}{c}\text { Seviye 2 } \\
\text { (Hastanede Tedavi) }\end{array}$ & 274 & 92 & 137 & 47 & 138 \\
\hline $\begin{array}{c}\text { Seviye 1 } \\
\text { (Hafif Yaralı) }\end{array}$ & 495 & 349 & 281 & 224 & 337 \\
\hline
\end{tabular}

Çalışmada kullanılan Senaryo 3 depremi için oluşabilecek can kaybı ve yaralanma tahmin sonuçları Tablo 7'de verilmiştir.

Tablo 7: Can kaybı ve yaralanma tahmin sonuçları: Senaryo $3(M=6.3)$

\begin{tabular}{|c|c|c|c|c|c|}
\hline \multirow{4}{*}{ Yaralanma Seviyesi } & \multicolumn{4}{|c|}{ Yöntem } & \multirow{3}{*}{ Ortalama } \\
\hline & \multicolumn{2}{|c|}{ CSM } & \multicolumn{2}{|c|}{ CM } & \\
\hline & KOERI & HAZUS & KOERI & HAZUS & \\
\hline & \multicolumn{5}{|c|}{ Kişi Sayısı } \\
\hline $\begin{array}{c}\text { Seviye } 4 \\
\text { (Can Kaybı) }\end{array}$ & 30 & 7 & 24 & 5 & 17 \\
\hline $\begin{array}{c}\text { Seviye } 3 \\
\text { (Ağır Yaralı) }\end{array}$ & 30 & 3 & 24 & 3 & 15 \\
\hline $\begin{array}{c}\text { Seviye } 2 \\
\text { (Hastanede Tedavi) }\end{array}$ & 67 & 23 & 58 & 20 & 42 \\
\hline $\begin{array}{c}\text { Seviye 1 } \\
\text { (Hafif Yaralı) }\end{array}$ & 131 & 99 & 123 & 99 & 11 \\
\hline
\end{tabular}

Depremin en belirgin etkisi yapılaşma süreci tamamlanmış çevrenin yıkımıdır. Deprem, yapılarda değişik oranlarda hasarlara sebebiyet vermektedir. Zaman zaman yapıların tüm fonksiyonlarını kaybetmesine neden olabilmektedir. Bu zararlar bölgenin ekonomik yapısını bozmaktadır. Senaryo depremleri sonucunda binalarda oluşan hasar seviyelerine göre inşaat alanları ve yapısal hasar oranları tablolarda gösterilmiştir. Mali kayıp hesaplamalarında, bir kat alanı ortalama $100 \mathrm{~m}^{2}$ olarak kabul edilmiştir. Çevre ve Şehircilik Bakanlığı tarafından Resmi Gazetede yayınlanmış "Mimarlık ve Mühendislik Hizmet Bedellerinin Hesabında Kullanılacak 2018 Yılı Yapı Yaklaşık Birim Maliyetleri Hakkında Tebliğ"de III. Sınıf Yapılar - A Grubu yapıların maliyeti 800 TL/m²'dir (URL-3 2018). Yapısal hasar kaynaklı mali kayıplar, toplam hasarlı inşaat alanı ile birim maliyetin çarpılması ile tahmin edilmiștir. Çalıșmada kullanılan Senaryo 1 depremine göre oluşacak hasar tiplerine göre elde edilen inşaat alanları Tablo 8'de verilmiştir.

Tablo 8: Hasar tiplerine göre inşaat alanları: Senaryo $1(M=6.8)$

\begin{tabular}{|c|c|c|c|}
\hline Hasar Seviyesi & İnşaat Alanı $\left.\mathbf{( m}^{\mathbf{2}}\right)$ & Hasar Oranları & $\begin{array}{c}\text { Hasarlı İnşaat Alanı } \\
\left(\mathbf{m}^{\mathbf{2}}\right)\end{array}$ \\
\hline Çok Ă̆ır Hasar & 10010 & $\% 100$ & 10100 \\
\hline Ă̆ır Hasar & 50611 & $\% 80$ & 40489 \\
\hline Orta Hasar & 246405 & $\% 40$ & 98562 \\
\hline Hafif Hasar & 947408 & $\% 0$ & 0 \\
\hline Hasarsız & 17494529 & & 243892 \\
\hline
\end{tabular}

Yapısal Hasar Kaynaklı Mali Kayıp $=243.892 \times 800 \approx 195$ Milyon TL

Çalışmada kullanılan Senaryo 2 depremine göre oluşacak hasar tiplerine göre elde edilen inşaat alanları Tablo 9'da verilmiştir. 
Tablo 9: Hasar tiplerine göre inşaat alanları: Senaryo $2(M=6.8)$

\begin{tabular}{|c|c|c|c|}
\hline Hasar Seviyesi & İnşaat Alanı (m²) & Hasar Oranları & Hasarlı İnşaat Alanı ( $\left.\mathbf{m}^{2}\right)$ \\
\hline Çok Ă̆ır Hasar & 247942 & $\% 100$ & 247942 \\
\hline Ăğır Hasar & 484233 & $\% 80$ & 387386 \\
\hline Orta Hasar & 1466687 & $\% 40$ & 586675 \\
\hline Hafif Hasar & 3007603 & $\% 10$ & 300760 \\
\hline Hasarsiz & 13542498 & $\% 0$ & 0 \\
\hline \multicolumn{3}{|c|}{ Toplam } & 1522763 \\
\hline
\end{tabular}

Yapısal Hasar Kaynaklı Mali Kayıp $=1.522 .763 x 800 \approx 1.218$ Milyar TL

Çalışmada kullanılan Senaryo 3 depremine göre oluşacak hasar tiplerine göre elde edilen inşaat alanları Tablo10'da verilmiştir.

Tablo 10: Hasar tiplerine göre inşaat alanları: Senaryo $3(M=6.3)$

\begin{tabular}{|c|c|c|c|}
\hline Hasar Seviyesi & İnşaat Alanı (m²) & Hasar Oranları & Hasarlı İnşaat Alanı $\left(\mathrm{m}^{2}\right)$ \\
\hline Çok Ağır Hasar & 100292 & $\% 100$ & 100292 \\
\hline Ăğır Hasar & 246133 & $\% 80$ & 196906 \\
\hline Orta Hasar & 773691 & $\% 40$ & 309476 \\
\hline Hafif Hasar & 1945529 & $\% 10$ & 194553 \\
\hline Hasarsiz & 15683318 & $\% 0$ & 0 \\
\hline \multicolumn{3}{|c|}{ Toplam } & 801227 \\
\hline
\end{tabular}

Yapısal Hasar Kaynaklı Mali Kayıp $=801.227 x 800 \approx 640$ Milyon TL

Çalışmada kullanılan üç farklı deprem senaryosu için elde edilen bina hasar tahmin sonuçlarının karşılaştırılması Tablo 11'de verilmiştir.

Tablo 11: Üç farklı deprem senaryosu için bina hasar tahmin sonuçlarının karşılaştırılması

\begin{tabular}{|c|c|c|c|}
\hline \multirow{2}{*}{ Hasar Seviyesi } & \multicolumn{3}{|c|}{ Toplam Bina Sayısına oranı } \\
\cline { 2 - 4 } & Senaryo 1 & Senaryo 2 & Senaryo 3 \\
\hline Çok Ă̆ır Hasar & $\% 1$ 'den az & $\% 2$ & $\% 1$ 'den az \\
\hline Ăğır Hasar & $\% 1.1$ & $\% 3$ & $1.40 \%$ \\
\hline Orta Hasar & $\% 4.2$ & $\% 9$ & $4.50 \%$ \\
\hline Hafif Hasar & $\% 9.9$ & $\% 17$ & $10.40 \%$ \\
\hline Hasarsız & $84 \%$ & $\% 69$ & $83.10 \%$ \\
\hline
\end{tabular}

En büyük yapısal hasarlar Senaryo 2 depreminde oluşmaktadır. Senaryo 2 ve Senaryo 3 depremleri aynı noktada kabul edilmiştir. Deprem büyüklüğünün azalması oluşacak hasarların azalmasına sebebiyet vermektedir. Farklı depremler için hasarlı inşaat alanlarının karşılaştırılması Tablo 12'de verilmiştir.

Tablo 12: Hasarlı tiplerine göre inşaat alanlarının $\left(m^{2}\right.$ karşılaştıııması

\begin{tabular}{|c|c|c|c|}
\hline Hasar Seviyesi & Senaryo 1 & Senaryo 2 & Senaryo 3 \\
\hline Çok Ağır Hasar & 10100 & 247942 & 100292 \\
\hline Ăğır Hasar & 40489 & 387386 & 196906 \\
\hline Orta Hasar & 98562 & 586675 & 309476 \\
\hline Hafif Hasar & 94741 & 300760 & 194553 \\
\hline
\end{tabular}


Deprem senaryolarına göre hesaplanan ortalama can kaybı ve yaralanma tahmin sonuçlarının karşılaştırılması Tablo 13'te gösterilmiştir.

Tablo 13: Can kaybı ve yaralanma tahmin sonuçlarının karşılaştırılması

\begin{tabular}{|c|c|c|c|}
\hline \multirow{2}{*}{ Yaralanma Seviyesi } & Senaryo 1 & Senaryo 2 & Senaryo 3 \\
\cline { 2 - 4 } & 26 & 57 & 17 \\
\hline $\begin{array}{c}\text { Seviye 4 } \\
\text { (Can Kaybı) }\end{array}$ & 24 & 52 & 15 \\
\hline $\begin{array}{c}\text { Seviye 3 } \\
\text { (Ağır Yaralı) }\end{array}$ & 65 & 138 & 42 \\
\hline $\begin{array}{c}\text { Seviye 2 } \\
\text { (Hastanede Tedavi) }\end{array}$ & 171 & 337 & 11 \\
\hline $\begin{array}{c}\text { Seviye 1 } \\
\text { (Hafif Yaralı) }\end{array}$ & & \\
\hline
\end{tabular}

Senaryo 1 ve Senaryo 2 depremlerinin büyüklüklerinin aynı olmasına karşın elde edilen sonuçlarda farklılıklar mevcuttur. $\mathrm{Bu}$ farklılıklar depremin konumu, deprem üretecek fayın özellikleri ve deprem kaynağına uzaklık farklılaşmasından kaynaklanmaktadır.

\section{Sonuçlar}

Depremlerden dolayı oluşabilecek hasarların hangi bölgedeki, ne tür yapıları en fazla etkileyeceğinin ve olası depremlerin ortaya çıkarabileceği sonuçların tahmin edilmesi depremlere hazırlanmak açısından önem arz etmektedir. Depremlerin değerlendirilmesi aşamasında ve depremlerin neden olabileceği zararların tahmininde kayıp tahmin analizleri önemli bir yer tutmaktadır. Bu analizlerle potansiyel zararlar ve kayıplar ile ilgili bilgilere ulaşılmaktadır.

Depremlerden dolayı oluşabilecek kayıpları azaltmak ve/veya en aza indirgemek için deprem açısından riskli bölgelerin belirlenmesi tek başına yeterli olmamaktadır. Bu bölgelerde imkanlar dahilinde alınabilecek önlemler kararlılıkla uygulamaya geçirilmelidir. Burada yöre halkına verilecek bilinçlendirme amaçlı eğitimler önemli bir yer tutmaktadır.

$\mathrm{Bu}$ çalışma, Kırşehir ilinde olabilecek depremlere karşı senaryolar oluşturmakta ve oluşturulan senaryolar sonucu karşılaşılabilecek kayıpları hesaplanmıştır. Kayıp tahmin modelleri risk azaltımı için gerekli en önemli araç olarak tanımlamaktadır. Kayıp tahmin modelleri sayesinde şehir plancılar ve afet yöneticileri potansiyel zararlar ve kayıplar üzerine kilit bilgilere ulaşabileceklerdir. Kayıp tahminlerinin doğal afetlerin değerlendirilmesi aşamasında çok önemli bir yere sahip olduğu ve kapsamlı bir ekonomik, sosyal ve demografik veri setinin geliştirilmesinin, depremlerin neden olabileceği zararların tahmininde sağlayacağı faydalar gözden kaçırılmamalıdır.

Kırşehir sınırları içinde yaklaşık \%55'i betonarme çerçeve olmak üzere 90.337 adet bina olduğu tespit edilmiştir. Betonarme çerçeve binaların yaklaşık \%93'ü 1-4 katlıdır. Seçilen deprem senaryosuna bağlı olarak binaların ortalama 1.396 ila 4.093 adedi (toplam binaların yaklaşık \%2 - \%5'i) tamir edilemeyecek ölçüde (ağır hasar + çok ağır hasar) hasar görmektedir. Orta ve hafif hasarlı bina adetleri, seçilen deprem senaryosuna bağlı olarak 12.743 ila 23.820 (toplam binaların \%14-\%26’sı) arasında tahmin edilmiştir.

Kırşehir sınırları içindeki nüfus 225.197 olarak tespit edilmiştir. Değişik yöntemler kullanılarak bulunan can kaybı tahminleri, seçilen senaryoya bağlı olarak ortalama 17-57 arasında değişmektedir. Hastane bakımı gerektirecek yaralı sayısı ise yine seçilen deprem senaryosuna bağlı olarak ortalama 42 - 138 kişi arasındadır.

Afet yönetimi, risk azaltma, planlama, hazırlıklı olma, müdahale ve iyileştirme konularındaki etraflıca risk-tabanlı zarar analizi yaparak can ve mal kaybını azaltmak, insanları ve kurumları doğal afetlerden korumak amacıyla kullanılabilmektedir. Çalışmada üç farklı senaryo depremi seçilmiştir. Her farklı deprem senaryosu için bina hasar, can kaybı ve yaralanma ile ekonomik kayıplar ayrı ayrı hesaplanmıştır.

Çalışmada kullanılan kayıp parametreleri bina envanterine bağlı olarak doğrudan ekonomik kayıpları işaret etmektedir. Bina hasarlarından kaynaklanacak toplam mali kayıplar (yapısal ve yapısal olmayan), dünya genelinde yapılmış araştırmalara göre yapısal hasarın iki (2) katı mertebesine ulaşabilmektedir. Bu hesaplamalar yapılırken depremden dolayı oluşacak ikincil ekonomik kayıplar da göz ardı edilmemelidir. Altyapı, iş gücü, vergi gelir kayıpları, tedavi giderleri, yıkım, enkaz kaldırma ve yeniden yapım maliyetleri gibi maliyetler de doğrudan olmayan kayıplar olarak değerlendirilmelidir. 
Yeni yapılacak yapıların ilgili yönetmeliklere uygun olarak tasarlanıp, inşa edilmesi deprem zararlarını azaltma yönünde ciddi bir yaklaşımdır. Mevcut yapı stoku için de deprem riskinin azaltılması yönünde destek olacak önlemlerin alınması önem arz etmektedir.

$\mathrm{Bu}$ tür çalışmalar ile herhangi bir yerleşim birimi için riskli bölgelerin derecelendirilmesi sağlanabilmektedir. Risk öncelik sıralaması yapılarak acil koruma tedbirlerinin alınacağı bölgeler belirlenebilmektedir.

Bu çalışma Kırşehir ili için deprem master planının hazırlanması ve risk yönetimi için ciddi katkılar sunmuş olacaktır. Ayrıca yörede deprem zararlarının azaltılması yönündeki çalışmalarda kullanılabilecektir.

Kırşehir ili için deprem sonrası hasar tespit verilerinin yeterli miktarda olmaması elde edilen sonuçların karşılaştırılmasına imkan vermemiştir. Bundan dolayı depremlerden sonra hasar tespit işlemlerinin bir veri tabanında bulunması bu tür çalıșmaların kontrolü açısından önem arz etmektedir.

Kayıp tahmin analizlerinin anlam kazanması çalışılan bölgedeki yapı stokunun özellikleri ile doğrudan alakalıdır. Yapı stok özelliklerinin elektronik bir ortamda sürekli güncellenerek tutulması gerekmektedir. Değişecek yapı stoku özelliklerinin bilinmesi ile kayıp tahmin analizleri tekrarlanarak sağlıklı sonuçlar elde edilebilecektir.

Çalışmada ayrıca farklı deprem senaryoları için en büyük yer hızları ve en büyük ivme değerleri için haritalarda elde edilmiştir. Depremin büyüklüğü, konumu, fay özellikleri ve yerel zemin koşulları yer hareketini etkilemektedir.

\section{Teşekkür}

Çevre ve Şehircilik Bakanlığı ve Bitlis Eren Üniversitesi arasında imzalanmış bulunan "Kentsel Dönüşüm Alanlarının Belirlenmesi ve Senaryo Afetlerin Oluşturulması İçin Yerel Yönetimlerin Verilerinin Kullanıldığı Coğrafi Bilgi Sistemi Tabanlı Otomasyon Sisteminin Oluşturulmasının Araştırılması ve Geliştirilmesi Projesi” kapsamında yapılan proje sonucunda üretilmiştir.

\section{Kaynaklar}

Bal İ.E., Crowley H., Pinho R., (2008), Displacement-based earthquake loss assessment for an earthquake scenario in Istanbul, Journal of Earthquake Engineering, 12(1), $12-22$.

Bommer J.J., Spence R., Erdik M., Tabuchi S., Aydinoglu N., Booth E., Del Re D., Peterken O., (2002), Development of an earthquake loss model for Turkish catastrophe insurance, Journal of Seismology, 6(3): 431-446.

Bozkurt E., (2001), Neotectonics of Turkey - a synthesis, Geodinamica Acta (Paris), 14, 3-30.

Crowley H., Bommer J.J., (2006), Modelling seismic hazard in earthquake loss models with spatially distributed exposure, Bulletin of Earthquake Engineering, 4, 249-273.

ELER, (2010), Earthquake Loss Estimation Routine, Technical Manual and Users Guide, Bogazici University, Department of Earthquake Engineering, Istanbul.

Erdik M., Zülfikar C., Demircioğlu M.B., Hancılar U., Şeşetyan K., Kamer Y., (2010), Earthquake shake mapping and loss assessment applications by ELER v2.0, Geophysical Research Abstracts, Vol. 12, EGU2010-14688-3.

Erdik M., Durukal E., (2008), Earthquake risk and its mitigation in Istanbul, Natural Hazards, 44(2), 181-197.

Erdik M., Aydinoglu N., Fahjan F., Sesetyan K., Demircioglu M., Siyahi B., Durukal E., Ozbey C., Biro Y., Akman H., Yuzugullu O., (2003), Earthquake risk assessment for Istanbul metropolitan area. Earthquake Engineering and Engineering Vibration, 2(1), 123.

Eyidoğan H., (2003), Tektonik ve Deprem Tehlikesi, 5. Ulusal Deprem Mühendisliği Konferans1, 26-30 Mayıs 2003, İstanbul.

Gömcü G., (2013), Kırşehir afet durumu raporu, http://investinkirsehir.com/assets/ilgilidosyalar/Kirsehir-Afet-Durum-Raporu.pdf, [Erişim 20 Mayıs 2016].

Hancilar U., Tuzun C., Yenidogan C., Erdik M., (2010), ELER software - a new tool for urban earthquake loss assessment, Natural Hazards and Earth System Sciences, 10, 2677-2696.

HAZUS-MH, (2003), Technical Manual, Federal Emergency Management Agency (FEMA), Washington, DC, USA.

Işı E., Kutanis M., Bal, İ.E., (2016), Displacement of the Buildings According to Site-Specific Earthquake Spectra, Periodica Polytechnica Civil Engineering, 60(1), 37-43.

Ișık E., Kutanis M., Bal İ.E., (2017), Loss estimation and seismic risk assessment in Eastern Turkey, Građevinar, 69(07), 581-592.

Işık E., Sağıroğlu Ç., Tozlu Z., Ustaoğlu S., (2018), Determination of urban earthquake risk for Kırşehir Province, Turkey, Yayımlanmamış makale.

KOERİ, (2002), Earthquake Risk Assessment for İstanbul Metropolitan Area, Report prepared for American Red Cross and Turkish Red Crescent, Bogazici University, Department of Earthquake Engineering, İstanbul, Turkey.

Maden N., Gelişli K., Eyüboğlu Y., Bektaş O., (2009), Two-and-three-dimensional crustal thickness of the eastern pontides (NE Turkey), Turkish Journal of Earth Sciences, 18(2), 225-238.

Makhoul N., Argyroudis S., (2018), Loss Estimation Software:Developments, Limitations and Future Needs, 16th European Conference on Earthquake Engineering, Thessaloniki, Greece.

Molina S., Lang D.H., Lindholm C.D., Lingvall F., (2010), User manual for the earthquake loss estimation tool: SELENA, NORSAR and Universidad de Alicante, http://selena.sourceforge.net/selenamanual.pdf, [Erişim 11 Mayıs 2018].

Özmen B., (2008), Ankara için Deprem Senaryosu, Ankara'nın Deprem Tehlikesi ve Riski Çalıştayı, 19 Mart 2008, Ankara.

Şahin G., (2016), 1938 Kırşehir (Akpınar) Depremi ve Bölgeye Etkileri, Tarih Okulu Dergisi, 9(16), 289-321.

Temiz U., (2004), Kırşehir dolayının neotektoniği ve depremselliği (Neotectonics and seismicity of the Kırşehir Region), Doktora Tezi, Ankara Üniversitesi Fen Bilimleri Enstitüsü, Ankara, 121s. 
Temiz U., Gökten Y.E., (2011), Ms 6.819 Nisan 1938 Akpınar (Kırşehir) Depreminin Coulomb Gerilme Analizi, Geological Bulletin of Turkey, 54(3), 81-92.

Türkelli N., (2008), Sismik Ağların Deprem Tehlike Analizlerine Katkısı, Boğaziçi Üniversitesi, Kandilli Rasathanesi ve Deprem Araştırma Enstitüsü, Jeofizik Bölümü, http://www.eies.itu.edu.tr/barkalecture7turkelli_barka_2005.pdf [Erişim 20 Mayıs 2016].

URL-1, (2007), Earthquake risk assessment MAEVIZ tutorial, Middle America Earthquake Center, University of Illinois at UrbanaChampaign, http://rcp.ncsa.uiuc.edu:8080/tutorials/MAEviz\%20Tutorial\%20Charleston\%20Bridges.pdf, [Erişim 20 May1s 2018].

URL-2, (2018), https://tdth.afad.gov.tr/, [Erişim 17 Temmuz 2018].

URL-3, (2016), http://www.kirsehir.gov.tr/nufus, [Erişim 20 Mayis 2016].

Yıldız N., (2008), Kırşehir ilinin depremselliği, Yüksek Lisans Tezi, Erciyes Üniversitesi, Fen Bilimleri Enstitüsü, Kayseri, 243s.

Yunatç1 A.A., Çetin K.Ö., (2007), Site Specific Seismic Response and Soil Liquefaction Triggering Assessment Integrated within Probabilistic Seismic Hazard Framework, Sixth National Conference on Earthquake Engineering, 17-20 October 2007, Istanbul.

Zülfikar A.C., Zülfikar Fercan N.Ö., Tunç S., Erdik M., (2017), Real-time earthquake shake, damage, and loss mapping for Istanbul metropolitan area, Earth, Planets and Space, 69:9, 1-15, doi: 10.1186/s40623-016-0579-x. 